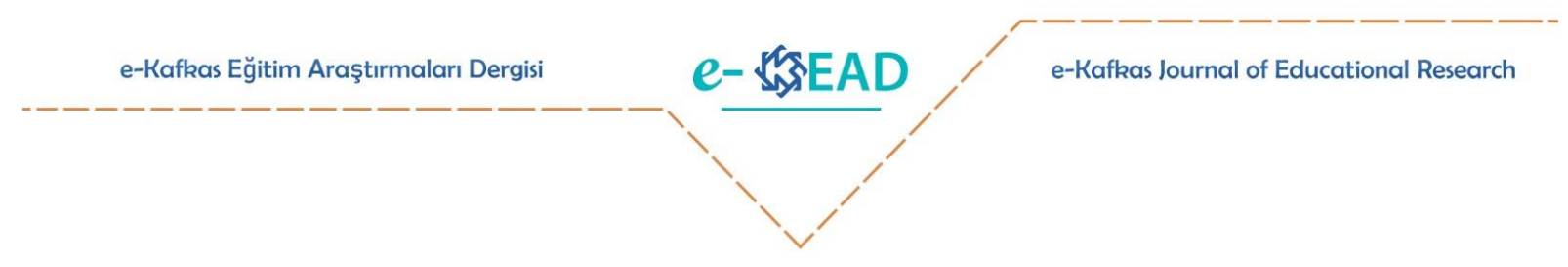

\title{
İlkokul Dördüncü Sınıf Öğrencilerinin Çevreye Yönelik Bilgi, Davranış ve Tutumlarının Belirlenmesi $^{1}$
}

\author{
Beyza Selin UZUN ${ }^{2}$ (D) Burcu ŞENLER ${ }^{3}$ (D) $\$
}

Atıf: Uzun, B. S. ve Şenler, B. (2020). İlkokul dördüncü sınıf öğrencilerinin çevreye yönelik bilgi, davranış ve tutumlarının belirlenmesi. e- Kafkas Eğitim Araştırmaları Dergisi, 7, 413-429. doi: 10.30900/kafkasegt.796058

Araştırma Makalesi

Geliş Tarihi:17.09.2020

Kabul Tarihi: 30.12 .2020

\section{$\ddot{O} \mathbf{z}$}

Bu çalışmanın amacı, ilkokul dördüncü sınıf öğrencilerinin çevreye yönelik bilgi, davranış ve tutum düzeylerini belirlemek ve bazı değişkenler açısından incelemektir. Çalışmada nicel araştırma yöntemlerinden tarama modeli kullanılmıştır. Çalışma üç aşamadan oluşmaktadır. Çalışmanın ilk aşamasında öğrencilerin çevreye yönelik bilgi, davranış ve tutumlarını ölçmek için Çevresel Bilgi Ölçeği, Çevresel Davranış Ölçeği ve Çevresel Tutum Ölçeği geliştirilmiştir. İkinci aşamada Ege Bölgesi’nde yer alan bir ilçedeki ilkokullarda öğrenim görmekte olan gönüllü 457 dördüncü sınıf öğrencisi ile pilot uygulama yapılarak ölçme araçlarının geçerlik ve güvenirlik hesaplamaları yapılmıştır. Son olarak da ölçekler Güneydoğu Anadolu Bölgesi’nde yer alan bir ildeki iki ilçeye bağlı ilkokullarda öğrenim görmekte olan gönüllü 292 dördüncü sınıf öğrencisine uygulanarak çalışmanın alt problemlerine cevap aranmıștır. Öğrencilerin ortalama puanları Çevresel Bilgi Ölçeği için ölçek ortalamasının üstündeyken, Çevresel Davranış Ölçeği ve Çevresel Tutum Ölçeği için maksimuma yakındır. Yapılan yordamsal analizler sonucunda çevreye yönelik bilgi, davranış ve tutum puanlarının cinsiyete göre farklılaşmadığı ancak kız öğrencilerin puanlarının daha yüksek olduğu bulunmuştur. Fen bilimleri dersi notuna göre yapılan incelemede bilgi ve tutum ölçeği puanlarının fen bilimleri dersi karne notuna göre anlamlı olarak farklılaştığı; davranış puanlarının fen bilimleri dersi karne notuna göre farklılaşmadığı saptanmıştır. Öğrencilerin çevreye yönelik bilgi, tutum ve davranış puanları arasında pozitif yönlü ve anlamlı ilişki tespit edilmiştir. Çalışmanın sonucunda, elde edilen bulgular alanyazında yer alan bilimsel araştırmalar ile tartışılmış ve çevre eğitimine katkısı olunabileceği düşünülen önerilerde bulunulmuştur.

Anahtar Sözcükler: İlkokul, çevresel bilgisi, çevresel davranış, çevresel tutum 
end, the findings have been discussed with the scientific researches in the literature and suggestions that can contribute to environmental education have been made.

Keywords: Primary school, environmental knowledge, environmental behavior, environmental attitude

\section{Giriş}

Canlılar yaşamlarını sürdürebilmek için fiziksel bir alana ihtiyaç duymaktadır. Çevre en genel anlamı ile bir canlının canlı ve cansız varlıklar ile birlikte yaşamını sürdürdüğü alan, doğal veya yapay ortam olarak tanımlanabilmektedir (Berkes ve Kışlalıoğlu, 1993; Çabuk ve Karacaoğlu, 2003). Sanayi devriminden itibaren başlayarak ilerleyen ve günümüzde ise hızına hız katarak devam eden teknolojik gelişmeler, doğal kaynakların hızla tüketilmesi, toplumların tüketim toplumuna dönüşmesi, yeşil alanların giderek azalarak gri alanların çoğalması gibi etkenler ekonomik döngüler ve toplumsal dengelerin yanında en çok çevremizi etkilemektedir. Bu etkenler insanların doğanın kaynaklarını kullanırken gitgide ona sahip olma çalışmaları neticesinde çevre ile ilgili problemler yaşanmasına neden olmaktadır (Sam, Gürsakal ve Sam, 2010). Dünyada güncel olarak yaşanan çevresel sorunların başında küresel ısınma ve iklim değişikliği sorunları gelmektedir. Bunlarla birlikte; biyolojik çeşitlilikte azalma ve ekosistemlerin tahrip edilmesi, nükleer kirlilikler, doğal kaynakların hızla tükenmesi, erozyon, çölleşme gibi sorunlar da oldukça etkilidir ve hem dünyanın hem de insanların yaşamında önemli rol oynamaktadır (Ertürk, 2009).

Ortaya çıkan çevre sorunlarının ciddi sonuçlar doğurmasıyla birlikte insanlarda, toplumlarda ve yönetimlerde; "Çevre sorunlarını önlemek için neler yapılabiliriz?" sorusu ön plana çıkmaya başlamıştır. Bu kapsamda verilen en kapsamlı cevap ise çevre sorunlarının henüz ortaya çıkmadan engellenmesi için çevre eğitimine önem verilmesi olmuştur. İnsanların çevre konusunda gerekli biçimde eğitilmesi ve bilgilendirilmesi gerekmektedir (Aydın ve Çepni. 2012). Bu bağlamda çevre bilgisi çevre eğitiminin bileşenlerinden biridir. Çevre bilgisi, genel anlamıla bireylerin sahip oldukları bilgiyle çevre konusundaki sorunları anlamalarına, bu sorunlara yönelik çözüm önerileri getirmeye, bu sorunların nedenleri hakkında fikirler oluşturmaya yardımcı olur (Öztürk, 2013). Dolayısıyla evre hakkında sadece bilgi sahibi olmak, çevre bilincine sahip olmanın bir parçası olarak görünmektedir. Bunun yanında çevre eğitimi; özünde bireylerin çevreye ve doğaya olan farkındalıklarını arttırarak sadece bilgi boyutunda değil, davranış boyutunda da bireylerde kalıcı ve olumlu etkiler bırakmayı amaçlamaktadır (Şimşekli, 2004). Bireylerin çevrelerine yönelik olumlu davranışlarının gözlenmesi ile bireylerde ve nihayetinde toplumun genelinde bir çevre bilinci oluşturmaktan söz edilebilmektedir. Bu sayede çevre sorunlarının temelinde yatan insan faktörünün ve bu faktörün dünyamız üzerindeki olumsuz etkilerinin en aza indirilebileceğinden bahsedilebilir (Ceger ve Erten, 2018). Çevreye yönelik olumlu davranışların kazandırılması sürecinde atılacak ilk adım bireylerin erken yaşta alacakları planlı ve programlı çevre eğitimi neticesinde, çevreye yönelik bilgi düzeylerinin artmasıyla birlikte, çevreye yönelik olumlu tutumlarının da arttırılmasıdır (Gökçe, Kaya, Aktay ve Özden, 2007; Yaşaroğlu ve Akdağ, 2013). İnsanoğlunun çevresine karşı takındığı olumlu tutumlar, çevresini sahiplenmesi, koruması gibi davranışların arkasında destekleyici bir his olarak görülebilmektedir (Karaismailoğlu, 2018; Karataş, 2013; Yaşaroğlu ve Akdağ, 2013). Bireylere verilecek çevre eğitimi, bireylerin çevreye yönelik olumlu tutumlara sahip olmasında ve bu tutumların daha sonrasında olumlu davranışlara dönüşmesinde oldukça önemlidir. Çevre hakkında yeteri kadar bilgi sahibi olan bireyler, çevreye yönelik olumlu tutumlar geliştirecek ve bu doğrultuda alışkanlıklar edineceklerdir. Çevre bilgisine sahip olan bireylerin bu bilgileri kullanması ve günlük yaşamlarında içselleştirmesi sonucunda, çevre bağlamında olumlu tutumlar gelişmeye başlamakta ve olumlu tutumların gelişmesi sonucunda da çevre dostu, çevreye karşı olumlu davranışlar sergilenmektedir (Karaismailoğlu, 2018; Öztürk, 2013).

Ülkemizde çevre eğitimi konusunda bu eğitimin en iyi ortaokul düzeyinde verilebileceği düşünülmüş ancak daha sonra bu fikir çevre eğitiminin erken yaşlarda başlaması gerektiği yönüne kaymıştır. Bunun nedenleri programlar ile ilkokul dördüncü sınıfta öğrencilerin çevre ile ilgili hava, toprak ve su kirliliği, sürdürülebilirlik ve madde döngüsü gibi kavramları öğrenebiliyor olmasıdır (Karaismailoğlu, 2018). Talim Terbiye Kurulu Başkanlığı tarafından 2018 yılında güncellenen ilköğretim kurumları öğretim programları incelendiğinde çevreye yönelik çalışmaların tüm disiplinlerde yer aldığı görülmektedir (Milli Eğitim Bakanlığı [MEB], 2018a, 2018b, 2018c, 2018d, 
2018e). İlköğretim programlarında yer alan çevre bilgisi ile ilgili içerikler öğrencilere kazandırılacak çevre bilinci açısından avantaj olarak görülebilmektedir. Çevre eğitiminin niteliğinin tartışıldığı günümüzde çevre eğitiminin bilgi aktarımı ve işlemlerin üzerinde daha çok davranış değişikliği olarak bireylerde gözlenebiliyor olabilmesi gerektiği vurgulanmaktadır. Buradan hareketle çevre eğitiminin varlığından çok çevre eğitiminin niteliği, öğrencilerin, bireylerin davranışlarına ne kadar yansıdığı önem kazanmaktadır (Ek, Kılıç, Öğdüm, Düzgün ve Şeker, 2009).

Yurtiçi ve yurt dışında ilkokul düzeyinde yapılan araştırmalar incelendiğinde; bu çalışmalarda çevreye yönelik duyarlığa (örn. Özdemir, 2010; Tecer, 2007), çevre sorunlarına yönelik görüş ve farkındalığa (örn. Doğanay ve Sağgöz, 2019; Gökçeli, 2015; Verdelone, Campbell ve Alexandrino 2019); çevre okuryazarlığına (Özsoy, 2010) ve öğretim programını incelemeye (örn. Atasoy, 2012; Yolcu, 2013) odaklanıldığg görülmektedir. Çocuklara yönelik çevre eğitiminin önemini vurgulamak ve çevresel farkındalığ arttırmak amacıyla çevresel bilgi, tutum ve davranışı kapsayan bütünleştirici bir çalışmanın yeni çalışmalara yol göstereceği düşünülerek bu araştırma gerçekleştirilmiştir. Bununla birlikte, temel eğitimde mevcut durumda çevre bilinci ve çevre dostu davranışların oluşup oluşmadığını değerlendirmek bağlamında geliştirilen ölçeğin çevre eğitimi konusunda ilgili alanyazına katk1 sağlayacağı düşünülmektedir. Bunlarla birlikte araştırma doğrultusunda temel eğitim düzeyinde olan ilkokul dördüncü sınıf öğrencilerinin çevreye yönelik bilgi, davranış ve tutum gibi özellikleri belirlenmiş olacak, bu kapsamda öğrencilerin çevre okuryazarı bireyler olarak yetiştirilmesine de katkı sağlamaya çalışılacaktır. Çalışmada genel itibari ile çevre okuryazarı bireyler olarak yetiştirilmesi öngörülen "İlkokul dördüncü sınıf öğrencilerinin çevreye yönelik bilgi, davranış ve tutumları nasıldır?" sorusunun cevabı aranmaktadır. Bu kapsamda ilkokul dördüncü sınıf öğrencilerinin çevreye yönelik bilgi, davranış ve tutumlarının daha net görülmesi amacıyla bir ölçeğin geliştirilmesi ve bu ölçeğin geçerlik, güvenirlik çalışmalarının yapılarak öğrencilere uygulanması, elde edilen verilerin yorumlanması ile kapsamlı bir araştırma yapılması düşünülmüştür. Bu yönden ele alınacak olduğunda temel eğitimin amaçları doğrultusunda çevre okuryazarı bireyler yetiştirilmesi için öğrencilerin ancak gerekli çevre bilgisine, çevreye yönelik olumlu tutumlara ve çevre dostu davranışlara sahip olması gerektiği görülmektedir. Araştırmanın özellikle temel eğitim seviyesinde çevreye yönelik bilgi, davranış ve tutumları tek seferde ölçebilecek bir ölçme aracının geliştirilmesi yönüyle oldukça önemli olduğu söylenebilir.

$\mathrm{Bu}$ çalışmada İlkokul dördüncü sınıf öğrencilerinin çevreye yönelik bilgi, davranış ve tutumlarının belirlenmesi ve çeşitli değişkenlere göre incelenmesi amaçlanmıştır. Dolayısıyla araştırmada cevap aranan alt problemler şunlardır:

- İlkokul dördüncü sınıf öğrencilerinin çevreye yönelik bilgi, davranış ve tutumları ne düzeydedir?

- İlkokul dördüncü sınıf öğrencilerinin çevreye yönelik bilgi, davranış ve tutumları cinsiyetlerine göre farklılık göstermekte midir?

- İlkokul dördüncü sınıf öğrencilerinin çevreye yönelik bilgi, davranış ve tutumları Fen Bilimleri dersi karne notuna göre değişmekte midir?

- İlkokul dördüncü sınıf öğrencilerinin çevreye yönelik bilgi, davranış ve tutumları arasında bir ilişki var midır?

\section{Yöntem}

\section{Araştırmanın Modeli}

Nicel araştırma yöntemlerinden biri olan tarama modelinde, bir örneklemde yer alan katılımcıların belirlenen özellikleri incelenir (Büyüköztürk, Kılıç Çakmak, Akgün, Karadeniz ve Demirel, 2014). Bu doğrultuda bu araştırma, tarama modeli kullanılarak gerçekleştirilmiştir. Yapılan araştırma üç aşamadan oluşmaktadır. Araştırmanın ilk aşamasında çevreye yönelik bilgi, davranış ve tutum ölçmek bir ölçme araçlarının geliştirilmesi, ikinci aşamasında geliştirilen ölçeğin pilot uygulamasının yapılması, üçüncü aşamasında ise çalışmanın alt problemlerine cevap aramak için ölçeklerin başka bir örnekleme uygulanması bulunmaktadır. 


\section{Evren ve Örneklem}

Araştırmanın evrenini Güneydoğu Anadolu Bölgesi'nde yer alan bir ilde öğrenim görmekte olan ilkokul dördüncü sınıf öğrencileri oluşturmaktadır. Araştırmanın örneklemini ise, uygun örnekleme yöntemi ile seçilen bu ile bağlı iki ilçede bulunan ilkokullarda öğrenim görmekte olan gönüllü 292 ilkokul dördüncü sınıf öğrencisi oluşturmaktadır. Örnekleme ait demografik özellikler Tablo 1'de sunulmuştur.

Tablo 1.

Demografik Özellikler

\begin{tabular}{lccc}
\hline \multirow{2}{*}{ Cinsiyet } & & $\mathrm{f}$ & $\%$ \\
\hline \multirow{3}{*}{ Fen Bilimleri dersi karne notu } & $\mathrm{K} 1 \mathrm{z}$ & 158 & 54.1 \\
\cline { 2 - 4 } & Erkek & 134 & 45.9 \\
\cline { 2 - 4 } & Çok iyi & 239 & 81.8 \\
\cline { 2 - 4 } & İyi & 44 & 15.1 \\
\hline
\end{tabular}

Tablo 1 incelendiğinde katılımcıların yarısından fazlasını kız öğrencilerin oluşturduğu, çoğunun Fen Bilimleri dersi karne notunun çok iyi olduğu görülmektedir.

\section{Veri Toplama Araçları}

\section{Demografik Bilgi Formu}

Demografik bilgi formu, araştırmaya katılan öğrencilerin araştırmaya yön vereceği düşünülen kişisel bilgilerini toplamak amacıyla araştırmacılar tarafından hazırlanmıştır. Formda öğrencilerin cinsiyet, bir önceki dönem fen bilimleri dersinden aldıkları karne notları ile ilgili sorular bulunmaktadır.

\section{“Çevremi Nasıl Görüyorum?” Formu}

Araştırmada kullanılan veri toplama aracını geliştirmek için öncelikle araştırmacı tarafından ilgili alanyazın taranmıştır. Alanyazın taranırken çevre, çevre eğitimi, çevreye yönelik bilgi, davranış ve tutum başlıkları altında özellikle durulmuştur. Alanyazının incelenmesi sonrasında toplam üç ölçekten ve 110 maddeden oluşan madde havuzu oluşturulmuştur. Madde havuzu oluşturulurken araştırmanın gerçekleştirileceği çalışma grubu dikkate alınarak maddelerin açık ve anlaşılır, sade bir dille yazılmış olmasına özen gösterilmiştir. Ardından kapsam geçerliği için iki ölçme ve değerlendirme uzmanı, beş fen bilimleri alan eğitimi uzmanı ve bir sınıf öğretmeni olmak üzere, toplam sekiz uzmanın görüşü alınarak bazı maddeler anketten çıkarılmıştır. Son haline getirilen ölçme aracı beş ilkokul dördüncü sınıf öğrencisine sunulmuş ve bütün maddelerin anlaşılır olduğu belirlenmiştir.

Pilot uygulama için ölçme aracı Ege Bölgesi'ndeki bir ilçede yer alan ilkokullarda öğrenim görmekte olan gönüllü 457 dördüncü sınıf öğrencisine uygulanmıştır. Yapı geçerliği için öncelikle her bir ölçeğe açımlayıcı faktör analizi yapılmıştır. Özdeğer grafikleri sonucunda üç ölçeğin de tek faktörlü olduğuna karar verilmiştir. Özdeğer 1 kriterine bakıldığında tek faktörlü yapının Çevresel Bilgi Ölçeği'ni \%55, Çevresel Davranış Ölçeği'ni \%61 ve Çevresel Tutum Ölçeği'ni ise \%54 açıkladığı görülmüştür. Ölçeklerde yer alan maddelerden her ölçek için tek faktöre 0.30'un altında yüklenen maddeler ölçme araçlarından çıkarılmıştır. Doğrulayıcı faktör analizi çalışmanın örneklemi olan 292 öğrenciden toplanan verilerle yapılmış ve sonuçları Çevresel Bilgi Ölçeği için $(\chi 2 / \mathrm{df}=4.82$, $\mathrm{CFI}=.89, \mathrm{NNFI}=.87, \mathrm{RMSEA}=.13)$, Çevresel Davranış Ölçeği için $(\chi 2 / \mathrm{df}=5.03, \mathrm{CFI}=.99, \mathrm{NNFI}$ $=.98$, RMSEA $=.10)$ ve Çevresel Tutum Ölçeği için $(\chi 2 / \mathrm{df}=4.94, \mathrm{CFI}=.93, \mathrm{NNFI}=.92$, RMSEA $=.12$ ) olarak hesaplanmıştır. Bu sonuçlar da ölçeklerin tek faktörlü yapısını desteklemiştir (bkz. Hu ve Bentler, 1999; Wheaton, Muthen, Alwin ve Summers, 1977).

Ölçeklerin güvenirliğini belirlemek için çevresel bilgi ölçeğine KR-20, çevresel davranış ve çevresel tutum ölçeklerine Cronbach's Alpha analizleri yapılmıştır. Yapılan analizler sonucunda 
güvenirliği düşük çıkan maddeler ölçeklerden çıkarılmıştır. Böylece ölçme araçları son halini almıştır (Ek 1).

\section{Çevresel Bilgi Ölçeği}

Öğrencilerin çevre ve çevre sorunları hakkında bilgi düzeylerini ölçmek amacıyla hazırlanan ölçek 18 maddeden oluşmaktadır. Ölçek maddeleri üç seçeneklidir. Her soru için yapılan cevaplamalar doğru, bilmiyorum ve yanlış şeklinde ayrılmıştır. İfadelerde doğru işaretleme yapanlara 1, bilmiyorum ve yanlış işaretleme yapanlara 0 puan verilerek değerlendirilmiştir. Çevresel bilgi ölçeğinin güvenirliği pilot çalışmada KR-20=.73 olarak bulunmuştur. Alt problemlerinin araştırıldığ çalışmada ise KR$20=.61$ olarak hesaplanmıştır.

\section{Çevresel Davranış Ölçeği}

Öğrencilerin çevreye duyarlı davranışlarını hangi sıklıkta yaptıklarını belirlemek amacıyla geliştirilen çevresel davranış ölçeğinde üçlü likert tipinde hazırlanan (1=Her zaman, $2=$ Ara Sira, 3 =Asla) sekiz davranış maddesi bulunmaktadır. Ölçeğin güvenirliği pilot çalışmada Cronbach's Alpha $=.92$ olarak hesaplanmıştır. Alt problemlerinin araştırıldığı çalışmada ise güvenirlik Cronbach's Alpha $=.69$ olarak hesaplanmıştır.

\section{Çevresel Tutum Ölçeği}

Öğrencilerin çevreye yönelik tutumlarını ölçmek amacıyla geliştirilen ölçek üçlü likert tipinde (1=Katılıyorum, 2=Kararsızım, 3=Katılmıyorum) on maddeden oluşmaktadır. Ölçeğin güvenirliği pilot çalışmada Cronbach's Alpha $=.85$ olarak hesaplanmıştır. Alt problemlerinin araştırıldığ çalışmada ise güvenirlik Cronbach's Alpha $=.69$ olarak hesaplanmıştır.

\section{Verilerin Analizi}

Araştırmacılar tarafindan geliştirilen ölçek formları numaralandırılarak SPSS 22 programına girilmiş ve elde edilen veriler analiz edilmiştir. Bilgi puanlarının Skewness değerlerinin .117 ile 1.954 arasında, Kurtosis değerlerinin ise .145 ile -1.261 arasında olduğu saptanmıştır. Davranış puanlarının Skewness değerlerinin .163 ile 1.966 arasında, Kurtosis değerlerinin ise -.844 ile 1.884 arasında olduğu tespit edilmiştir. Tutum puanlarının ise Skewness değerlerinin .038 ile 1.954 arasında, Kurtosis değerlerinin ise -.162 ile 1.884 arasında olduğu görülmüştür. Skewness ve Kurtosis değerleri [+2,-2] arasında olduğu için verilerin normal dağılım gösterdiği belirlenmiştir (bkz. George ve Mallery, 2010). $\mathrm{Bu}$ doğrultuda yapılan analizlerde parametrik analiz yöntemleri tercih edilmiştir. İkili grupların karşılaştırılmasında bağımsız $\mathrm{t}$ testleri kullanılmıştır. Bu analizler için istatistiksel anlamlılık değeri $\mathrm{p}<.05$ olarak belirlenmiştir. Bilgi, davranış ve tutum ölçekleri arasındaki ilişkilerin belirlenmesi için Pearson korelasyon analizi yapılmışıı. Analiz sonuçlarının yorumlanmasında Cohen (1988) tarafından belirlenen parametre değerleri kullanılmıştır. Buna göre $r=10$ zayıf, $r=.30$ orta ve $r=.50$ yüksek düzeyde ilişkiyi göstermektedir (Cohen, 1988).

\section{Bulgular}

\section{Öğrencilerin Çevreye Yönelik Bilgi, Davranış ve Tutum Puan Düzeyleri}

İlkokul dördüncü sınıf öğrencilerinin çevreye yönelik bilgi, davranış ve tutum puanları betimsel analiz yapılarak incelenmiştir. Öğrencilerin ölçeklerden aldıkları minimum, maksimum ve ortalama puanlar Tablo 2'de verilmiştir.

Tablo 2.

Öğrencilerin Ölçeklerden Aldıkları Puanların Betimsel Analizi

\begin{tabular}{lccccc}
\hline & $\mathrm{N}$ & Minimum & Maksimum & $\overline{\mathrm{x}}$ & $\mathrm{SS}$ \\
\hline Bilgi & 292 & 4.00 & 18.00 & 13.81 & 2.97 \\
\hline Davranış & 292 & 13.00 & 24.00 & 22.59 & 2.01 \\
\hline Tutum & 292 & 17.00 & 30.00 & 27.39 & 2.48 \\
\hline
\end{tabular}

Tablo 2'ye göre üç ölçek için de öğrencilerden tam puan alanlar bulunmaktadır. Öğrencilerin ortalama puanları Çevresel Bilgi Ölçeği için ölçek ortalamasının üstündeyken, Çevresel Davranış ve Çevresel Tutum ölçekleri için maksimuma yakındır. 


\section{Cinsiyet Değişkenine Yönelik Bulgular}

İlkokul dördüncü sınıf öğrencilerinin cinsiyet dağılımlarının çevreye yönelik bilgi, davranış ve tutum puanlarına etkisi bağımsız $t$ testleri ile incelenmiştir ve sonuçları Tablo 3 'te verilmiştir.

Tablo 3.

Öğrencilerin Ölçeklerden Aldıkları Puanların Cinsiyet Değişkenine Göre Bağımsız t Testi Sonuçları

\begin{tabular}{lccccccc}
\hline Ölçek & Cinsiyet & $\mathrm{N}$ & $\overline{\mathrm{x}}$ & $\mathrm{SS}$ & $\mathrm{sd}$ & $\mathrm{t}$ & $\mathrm{p}$ \\
\hline \multirow{2}{*}{ Bilgi } & $\mathrm{K} 1 \mathrm{z}$ & 158 & 14.00 & 3.25 & 290 & .59 & .557 \\
\cline { 2 - 8 } & Erkek & 134 & 13.78 & 2.99 & & & \\
\hline \multirow{2}{*}{ Davranış } & Kiz & 158 & 22,78 & 1.82 & 290 & 1.72 & .086 \\
\cline { 2 - 8 } & Erkek & 134 & 22,38 & 2.20 & & & .462 \\
\hline \multirow{2}{*}{ Tutum } & Kiz & 158 & 27.52 & 2.40 & 290 & .74 & \\
& Erkek & 134 & 27.30 & 2.70 & & & \\
\hline
\end{tabular}

Tablo 3’te görüldüğ̈̈ gibi öğrencilerin bilgi ölçeği puanlarında erkek öğrenciler ( $\bar{x}_{\text {be }}=13.78$, $\mathrm{SS}=2.99)$ ile kız öğrenciler $\left(\overline{\mathrm{x}}_{\mathrm{bk}}=14.00, \mathrm{SS}=2.99\right)$ arasında anlamlı bir fark saptanmamıştır $(t(290)=.59$, p>.05). Aynı şekilde öğrencilerin çevresel davranış ölçeğinden alınan puanlarında erkek öğrenciler $\left(\overline{\mathrm{x}}_{\mathrm{de}}=22.38, \mathrm{SS}=2.20\right)$ ile kız öğrenciler $\left(\overline{\mathrm{x}}_{\mathrm{dk}}=22.78, \mathrm{SS}=1.82\right)$ arasında anlamlı bir fark bulunmamıştır $(t(290)=1.72, \mathrm{p}>.05)$. Son olarak, öğrencilerin çevresel tutum ölçeğinden alınan puanlarında erkek öğrenciler $\left(\overline{\mathrm{x}}_{\mathrm{te}}=27.30, \mathrm{SS}=2.70\right)$ ile kız öğrenciler $\left(\overline{\mathrm{x}}_{\mathrm{tk}}=27.52, \mathrm{SS}=2.40\right)$ arasında anlamlı bir fark bulunmamıştır $(t(290)=.74, \mathrm{p}>.05)$. Analiz sonuçlarında elde edilen bulgularda fark anlamlı olmasa da ilkokul dördüncü sınıf ögrencilerinin çevreye yönelik bilgi, davranış ve tutum puanları cinsiyet değişkenine göre incelendiğinde kız öğrencilerin ölçeklerden aldıkları ortalama puanların erkek öğrencilerden daha yüksek olduğu belirlenmiştir.

\section{Karne Notu Değişkenine Yönelik Bulgular}

İlkokul dördüncü sınıf öğrencilerinin çevreye yönelik bilgi, davranış ve tutum puanlarının Fen Bilimleri dersi karne notuna göre ortalama ve standart sapma değerleri Tablo 4'te gösterilmiştir. Karne notu $5=$ çok iyi, $4=$ iyi, $3=$ orta, $2=$ kötü, $1=$ çok kötü olarak sınıflandırılmıştır.

Tablo 4.

Karne Notu Değişkenine Göre Ölçeklerden Alınan Puanlar

\begin{tabular}{lcccc}
\hline & Karne Notu & $\mathrm{N}$ & $\overline{\mathrm{x}}$ & $\mathrm{SS}$ \\
\hline \multirow{3}{*}{ Bilgi } & Çok İyi & 239 & 14.36 & 3.00 \\
\cline { 2 - 5 } & İyi & 44 & 12.07 & 2.81 \\
\cline { 2 - 5 } Davranış & Orta & 9 & 10.55 & 3.00 \\
& Çok İyi & 239 & 22.72 & 1.95 \\
\cline { 2 - 5 } & İyi & 44 & 22.39 & 2.92 \\
\cline { 2 - 5 } Tutum & Orta & 239 & 27.67 & 2.47 \\
& Çok İyi & 44 & 26.69 & 2.37 \\
\hline & İyi & 9 & 24.78 & 2.63 \\
\hline
\end{tabular}

Tablo 4 incelendiğinde öğrencilerin Fen Bilimleri dersi karne notu çok iyi olan öğrenciler çevresel bilgi, davranış ve tutum ölçeklerinden orta not ve iyi not alan öğrencilerden daha yüksek ortalamaya sahip olduğu görülmüştür. Orta nota sahip öğrenci sayısı otuzun altında yer aldığ için yordamsal analizden çıkarılmış (bkz. Pallant, 2016) ve kalan gruplar bağımsız t-testleri ile incelenmiştir (bkz. Tablo 5). 
Tablo 5.

Öğrencilerin Ölçeklerden Aldıkları Puanların Karne Notu Değişkenine Göre Bağımsız t Testi Sonuçları

\begin{tabular}{lccccccc}
\hline Ölçek & Karne Notu & $\mathrm{N}$ & $\overline{\mathrm{x}}$ & $\mathrm{SS}$ & $\mathrm{sd}$ & $\mathrm{t}$ & $\mathrm{p}$ \\
\hline \multirow{2}{*}{ Bilgi } & Çok iyi & 239 & 14.36 & 3.00 & 281 & 4.73 & .000 \\
\cline { 2 - 8 } & İyi & 44 & 12.07 & 2.81 & & & \\
\hline \multirow{2}{*}{ Davranış } & Çok iyi & 239 & 22.72 & 1.82 & 281 & 1.06 & .292 \\
\cline { 2 - 8 } & İyi & 44 & 22.39 & 2.20 & & & .002 \\
\hline \multirow{2}{*}{ Tutum } & Çok iyi & 239 & 27.66 & 2.47 & 281 & 3.06 & \\
& İyi & 44 & 26.69 & 2.37 & & & \\
\hline
\end{tabular}

Tablo 5'te görüldüğü gibi öğrencilerin bilgi ölçeği puanlarında karne notu çok iyi olan öğrenciler $\left(\overline{\mathrm{x}}_{\mathrm{bci}}=14.36, \mathrm{SS}=3.00\right)$ ile iyi olan öğrenciler $\left(\overline{\mathrm{x}}_{\mathrm{bi}}=12.07, \mathrm{SS}=2.81\right)$ arasında notu çok iyi olan öğrenciler lehine anlamlı bir fark saptanmıştır $(t(281)=4.73, \mathrm{p}<.05)$. Öğrencilerin çevresel davranış ölçeğinden alınan puanlarında karne notu çok iyi olan öğrenciler $\left(\overline{\mathrm{x}}_{\mathrm{dç}}=22.72, \mathrm{SS}=1.82\right)$ ile iyi olan öğrenciler $\left(\overline{\mathrm{x}}_{\mathrm{di}}=22.39, \mathrm{SS}=2.20\right)$ arasında anlamlı bir fark bulunmamıştır $(t(281)=1.06, \mathrm{p}>.05)$. Son olarak, öğrencilerin çevresel tutum ölçeğinden alınan puanlarında karne notu çok iyi olan öğrenciler $\left(\overline{\mathrm{x}}_{\mathrm{tc} i}=27.66, \mathrm{SS}=2.47\right)$ ile iyi olan öğrenciler $\left(\overline{\mathrm{x}}_{\mathrm{ti}}=26.69, \mathrm{SS}=2.37\right)$ arasında notu çok iyi olan öğrenciler lehine anlamlı bir fark tespit edilmiştir $(t(281)=3.06, \mathrm{p}<.05)$.

\section{Öğrencilerin Çevreye Yönelik Bilgi, Davranış ve Tutumları Arasındaki İlişkiye Yönelik Bulgular}

İlkokul dördüncü sınıf öğrencilerinin çevreye yönelik bilgi, davranış ve tutumları arasındaki ilişkinin olup olmadığını incelemek amacıyla Pearson korelasyon analizi uygulanmıştır. Tablo 6'da Pearson korelasyon analizi sonuçları gösterilmiştir.

Tablo 6.

Çevreye Yönelik Bilgi, Davranış ve Tutum Puanları Arasındaki İlişki Düzeyi

\begin{tabular}{llll}
\multicolumn{5}{c}{} & \multicolumn{4}{c}{ Bilgi Düzeyi } & Tutum Düzeyi & Davranış Düzeyi \\
\hline Bilgi Düzeyi & 1 & & \\
\hline Tutum Düzeyi & $.500^{* *}$ & 1 & 1 \\
\hline Davranış Düzeyi & $.399^{* *}$ & $.556^{* *}$ & \\
\hline
\end{tabular}

**0,01 düzeyinde anlamlı ilişki

Tablo 6'ya göre ilkokul dördüncü sınıf öğrencilerinin bilgi ve tutum düzeyleri arasında pozitif yönlü yüksek düzeyde ve anlamlı bir ilişki $(r=.500, \mathrm{p} \leq .001)$; çevreye yönelik bilgi ve davranış düzeyleri arasında pozitif yönlü orta düzeyde ve anlamlı bir ilişki $(r=.399, \mathrm{p} \leq .001)$ ve çevreye yönelik tutum ve davranış düzeyleri arasında pozitif yönlü, yüksek düzeyde ve anlamlı bir ilişki $(r=0.556$, $\mathrm{p}<0.01)$ olduğu tespit edilmiştir.

\section{Tartışma, Sonuç ve Öneriler}

$\mathrm{Bu}$ çalışmada ilkokul dördüncü sınıf öğrencilerinin çevreye yönelik bilgi, davranış ve tutumları belirlenmiş ve çeşitli değişkenlere göre incelenmiştir. Öncelikle çalışmada kullanılması planlanan ölçekler geliştirilmiştir. Yapılan faktör analizleri ve güvenirlik hesaplamaları sonucunda ölçeklerin geçerliği ve güvenirliği sağlanmıştır. Ardından alt problemlerin araştırılmasına geçilmiştir. Analiz sonuçlarına göre öğrencilerin ortalama puanları Çevresel Bilgi Ölçeği için ölçek ortalamasının üstündedir. Çevresel davranış ve Çevresel Tutum Ölçeği puanları ise ölçekten alınacak maksimum puana yakındır. Sönmez ve Yerlikaya (2017) yaptıkları çalışmada ortaokul öğrencilerinin çevresel bilgi düzeylerinin ortalamanın az da olsa üzerinde bir değer alırken, çevresel tutum ölçeği puanlarının daha yüksek değer aldığını bulmuşlardır. Çevreye yönelik bilgi, davranış ve tutum puanlarının cinsiyet değişkenine bağlı olarak değişmediği saptanmıştır. Ancak çevreye yönelik bilgi ölçeği puanları cinsiyet değişkenine göre incelendiğinde kız öğrencilerin erkek öğrencilerden daha yüksek puan aldığı sonucuna ulaşılmıştır. Atasoy (2005) yaptığı çalışmada çevre bilgi ölçeğinden kız öğrencilerin erkek öğrencilerden daha yüksek puan aldıklarını tespit etmiştir. Öte yandan cinsiyet değişkeni ile çevresel bilgi puanları arasında anlamlı farklılık bulunmayan çalışmalar da vardır. Akyol ve Kahyaoğlu (2012), Alp, Ertepınar, Tekkaya ve Yılmaz (2006), Makki, Khalick ve Boujaoudes (2003) ve Yaşar (2013) 
yaptıkları araştırmalarıyla ortaokul öğrencilerinin çevresel bilgi puanları ile cinsiyet değişkeni arasında ilişki olmadığı sonucuna ulaşmışlardır. Dolayısı ile bu araştırmalar bu çalışmayı destekler niteliktedir. Araştırmada çevreye yönelik davranışın cinsiyete göre farklılaşmadığı fakat kız öğrencilerin davranış ölçeğinden almış oldukları puanların erkek öğrencilerden daha yüksek olduğu görülmüştür. Karaismailoğlu (2018) da yapmış olduğu çalışmada cinsiyet değişkeninin öğrencinin çevre dostu davranış sergilemesi üzerinde etkisi olmadığı sonucuna ulaşmıştır. Çalışmada ayrıca çevreye yönelik tutum cinsiyete göre incelenmiş ve anlamlı bir sonuç çıkmamasına rağmen kız öğrencilerin tutum puanları erkek öğrencilerden fazla bulunmuştur. Yapılan benzer pek çok çalışmada çevresel tutum için farklı düzeylerdeki kız öğrencilerin lehine anlamlı fark olduğu sonucuna ulaşılmıştır (örn. Alp vd., 2006; Atasoy ve Ertürk, 2008; Bayık Temel, Özkahraman ve Şenyurt, 2011; Ekici, 2005; Özdemir Özden ve Öztürk, 2019; Tuncer, Ertepınar, Tekkaya ve Sungur, 2005). Bu çalışma sonucunda kız öğrencilerin çevresel bilgi, davranış ve tutum puanları erkek öğrencilerden daha yüksek çıkmıştır. Bu bağlamda kız öğrencilerin sahip oldukları çevresel bilgiyi, çevresel davranış ve tutuma dönüştürme konusunda erkeklerden daha iyi düzeyde oldukları söylenebilir.

Öğrencilerin çevreye yönelik bilgi ölçeği sonuçlarına bakıldığında Fen Bilimleri karne notuna göre anlamlı bir farklılı̆ga rastlanmıştır. Bu anlamlı fark ise fen notu çok iyi olan öğrencilerin lehinedir dolayısıyla fen bilimleri ders notu arttıkça bilgi puanlarının da arttı̆̆ 1 görülmektedir. Öğrencilerin çevreye yönelik davranış ölçeği sonuçlarına bakıldığında Fen Bilimleri karne notuna göre anlamlı bir farklılık saptanmamıştır. Özdemir Özden ve Öztürk (2019), ortaokul öğrencileri ile yapmış olduğu çalışmasında öğrencilerin akademik başarıları arttıkça daha yüksek çevresel sorumlu vatandaşlık davranışı ve tutumlarının arttığını ifade etmiştir. Ancak Yaşar (2013) ise yaptığı araştırmada öğrencilerin fen notlarının çevresel davranışlarına etkisi olmadığı sonucuna ulaşmıştır. Öğrencilerin çevresel tutum puanlarının fen bilimleri ders notuna göre farklılaştığı bulunmuştur. Fen bilimleri ders notu çok iyi olan öğrencilerin çevresel tutum puanları, notu iyi olan öğrencilerin çevresel tutum puanlarından daha yüksektir. Gökçe, Kaya, Aktay ve Özden (2007), tarafından yapılan araştırmada ortaokul öğrencilerinin akademik başarısı arttıkça çevresel tutum puanlarının yükseldiği görülmüştür. Benzer şekilde bazı araştırmalarda (Teyfur, 2008; Yilmaz, Boone ve Anderson 2004) öğrencinin akademik başarısı arttıkça çevresel tutum ve davranış puanlarının arttığı görülmüştür. Araştırma sonucunda elde edilen bulgulara göre öğrencilerin akademik başarıları arttıkça çevresel bilgi, davranış ve tutum düzeylerinin yükseldiği görülmüştür.

İlkokul öğrencilerinin çevresel bilgi ve tutumları arasında güçlü ve pozitif yönlü anlamlı bir ilişki olduğu belirlenmiştir. Bu sonuç, öğrencilerin çevreye yönelik bilgi düzeyleri arttıkça çevreye dair tutumlarının geliştiğini ifade etmektedir. Benzer şekilde öğrencilerin çevreye yönelik tutumları arttıkça çevreye dair bilgi düzeylerinin de arttığı söylenebilir. Sönmez ve Yerlikaya (2017) ortaokul öğrencilerinin çevresel bilgi ve tutum puanları arasında çok güçlü olmasa da anlamlı ve pozitif yönlü bir ilişkinin olduğunu ortaya koymuşlardır. Öğrencilerin çevresel bilgi ve davranışları arasında çok güçlü olmasa da anlamlı bir ilişki vardır. İlkokul öğrencilerinin çevreye yönelik tutum ve davranış düzeyleri arasında pozitif yönlü, yüksek düzeyde ve anlamlı bir ilişki vardır. Öğrencilerin çevreye yönelik tutumları arttıkça çevreye yönelik davranışlarının olumlu yönde gelişme gösterdiği söylenebilir. Yaşar (2013) ilköğretim ikinci kademe öğrencileri ile yapmış olduğu çalışmasında benzer şekilde öğrencilerin çevresel tutumları ile çevresel davranış ve çevresel bilgileri arasında orta düzeyde, pozitif yönlü anlamlı bir ilişkiye ulaşmıştır.

Araştırma sonucunda elde edilen sonuçlara bakılarak, temel eğitimden başlanılarak verilecek çevre eğitiminin daha etkili olabilmesi için okullarda öğrencilerin sadece bilgilerini arttırmaya yönelik değil çevreye ilişkin olumlu tutum ve davranışlara sahip olmalarını sağlayacak etkinliklere ve çalışmalara yer verilebilir; bu kapsamda organizasyonlar düzenlenebilir. 


\section{Kaynakça}

Akyol, B., ve Kahyaoğlu, H. (2012). İlköğretim ikinci kademe öğrencilerinin çevre bilgi düzeyleri üzerine bir çalışma Niğde örneği. X. Ulusal Fen Bilimleri ve Matematik Kongresi, Niğde.

Alp, E., Ertepınar, H., Tekkaya, C. ve Yılmaz, A. (2006, Eylül). İlköğretim öğrencilerinin çevreye yönelik tutum ve bilgileri üzerine bir çalışma. VII. Ulusal Fen ve Matematik Eğitimi Kongresi, Ankara.

Atasoy, E. (2005). Çevre için eğitim: ilköğretim öğrencilerinin çevresel tutum ve çevre bilgisi üzerine bir çalışma (Yayınlanmamış Doktora Tezi), Uludağ Üniversitesi Sosyal Bilimler Enstitüsü, Bursa.

Atasoy, Ü. Ö. (2012). İlköğretim müfredatında yer alan çevre konularındaki FTTÇ kazanımlarına ulaşılma düzeyi ve ögrencilerin bu konulara karşı tutumlarının araştırılması (Yayınlanmamış Yüksek Lisans Tezi). Gazi Üniversitesi Eğitim Bilimleri Enstitüsü, Ankara.

Atasoy, E. ve Ertürk, H. (2008). İlköğretim öğrencilerinin çevresel tutum ve çevre bilgisi üzerine bir alan araştırması. Erzincan Eğitim Fakültesi Dergisi, 1(10). 105-122.

Aydın, F. ve Çepni, O. (2012). İlköğretim ikinci kademe öğrencilerinin çevreye yönelik tutumlarının bazı değişkenler açısından incelenmesi (Karabük ili örneği). Dicle Üniversitesi Ziya Gökalp Eğitim Fakültesi Dergisi, 18, 189-207.

Bayık Temel, A., Özkahraman, Ş. ve Şenyurt, A. (2011). Üniversite öğrencilerinin çevresel konulara duyarl11ıklarının incelenmesi. Süleyman Demirel Üniversitesi Sağllk Bilimleri Enstitüsü Dergisi, 2(1), 8-15.

Berkes, F. ve Kışlalığlu, M. (1993). Ekoloji ve çevre bilimi. İstanbul: Remzi Kitabevi.

Büyüköztürk, Ş., Kılıç-Çakmak, E., Akgün, Ö., Karadeniz, Ş., ve Demirel, F. (2014). Bilimsel araştırma yöntemleri. Ankara: Pegem Akademi

Ceger, B. ve Erten, S. (2018). Investigation of the information, attitude and behaviors of the conservatory secondary school students around the environment. The Eurasia Proceedings of Educational \& Social Sciences (EPESS), 9, 182-192.

Cohen J. (1988). Statistical power analysis for the behavioral sciences. New York, NY: Routledge Academic.

Çabuk, B. ve Karacaoğlu, Ö. C. (2003). Üniversite öğrencilerinin çevre duyarlılıklarının incelenmesi. Ankara Üniversitesi Eğitim Bilimleri Fakültesi Dergisi, 36, 1-2.

Doğanay, G. ve Sağgöz, G. (2019). İlkokul öğrencilerinin çevre ve çevre sorunlarına ilişkin görüşlerinin incelenmesi (Giresun örneği). Anadolu Üniversitesi Eğitim Fakültesi Dergisi, 3, $1-20$.

Ek, H. N., Düzgün, G., Kılıç, N., Öğdüm, P. ve Şeker, S. (2009). Adnan menderes üniversitesinin farklı akademik alanlarında öğrenim gören ilk ve son sınıf öğrencilerinin çevre sorunlarına yönelik tutumları ve duyarlılıkları. Kastamonu Eğitim Dergisi, 17, 125-136.

Ekici, G. (2005). Lise öğrencilerinin çevre eğitimine yönelik tutumlarının incelenmesi. Eğitim Araştırmaları Dergisi 18, 71-83.

Ertürk, H. (2009). Çevre bilimleri. Ankara: Ekin Yayınevi.

George, D., \& Mallery, M. (2010). SPSS for Windows Step by Step: A Simple Guide and Reference, 17.0 update (10a ed.) Boston: Pearson.

Gökçe, N., Kaya, E., Aktay, S. ve Özden M. (2007). Elemantary students' attitudes towards environment. Elemantary Education Online, 6, 452-468.

Gökçeli, F. K. (2015). Çevre eğitimi programının 48-66 aylık çocukların çevresel farkındalıklarına etkisi (Yayınlanmamış Doktora Tezi), Gazi Üniversitesi Eğitim Bilimleri Enstitüsü, Ankara.

Hu,L. T., \& Bentler,P.M. (1999). Cutoff criteria for fit indexes in covariance structure analysis: Conventioal criteria versus new alternatives. Structural Equation Modeling, 6(1),1-55.

Karaismailoğlu, E. S. (2018). Öğretmenlerin çevrebilinci düzeyinin belirlenmesi-Ankara Etimesgut örneği (Yayınlanmamış Yüksek Lisans Tezi). Hacettepe Üniversitesi Eğitim Bilimleri Enstitüsü, Ankara.

Karataş, A. (2013). Çevre bilincinin gelişstirilmesinde çevre eğitiminin rolü ve Niğde Üniversitesi Eğitim Fakültesi örneği (Yayımlanmamış Doktora Tezi). Ankara Üniversitesi Sosyal Bilimler Enstitüsü, Ankara. 
Makki, M. H., Khalıck, F. A. \& Boujaode, S. (2003). Lebanese secondary school students' environmental knowledge and attitudes. Environmental Education Research, 9, 21-33.

Milli Eğitim Bakanlığı. (2018a). Fen bilimleri dersi öğretim programı. Erişim adresi http://mufredat. meb.gov.tr/ProgramDetay.aspx?PID=325.

Milli Eğitim Bakanlığı. (2018b). Hayat bilgisi dersi öğretim programı. Erişim adresi http://mufredat. meb.gov.tr/ProgramDetay.aspx?PID=326.

Milli Eğitim Bakanlığı (2018c). Matematik dersi öğretim programı. Erişim adresi http://mufredat. meb.gov.tr/ProgramDetay.aspx?PID=329.

Milli Eğitim Bakanlığı (2018d). Sosyal bilgiler dersi öğretim programı. Erişim adresi http://mufredat. meb.gov.tr/ProgramDetay.aspx?PID=354.

Milli Eğitim Bakanlı̆̆ (2018e). Türkçe dersi öğretim programı. http://mufredat. meb.gov.tr/ProgramDetay.aspx?PID=663.

Özdemir, O. (2010). Doğa deneyimine dayalı çevre eğitiminin ilköğretim öğrencilerinin çevrelerine yönelik algı ve davranışlarına etkisi. Pamukkale Üniversitesi Eğitim Fakültesi Dergisi, 27, $125-138$.

Özdemir Özden, D., ve Öztürk, C. (2019). Birer çevresel vatandaş olarak ilköğretim öğrencileri: 6. 7. ve 8. sınıf öğrencilerinin çevresel sorumlu vatandaş davranışlarının incelenmesi. Eskisehir Osmangazi Üniversitesi Sosyal Bilimler Dergisi, 20, 363-392.

Özsoy, S. (2010). Effects of eco-school application on elementary school students' environmental literacy levels (Yayınlanmamış Doktora Tezi). Ortadoğu Teknik Üniversitesi Sosyal Bilimler Enstitüsü, Ankara.

Öztürk, E. (2013). Uluslararası bir çevre eğitimi projesinin fen ve teknoloji öğretmen adaylarının çevre bilincine etkisi (Yayınlanmamış Doktora Tezi). Hacettepe Üniversitesi Eğitim Bilimleri Enstitüsü, Ankara.

Pallant, J. (2016). SPSS survival manual a step by step guide to data analysis using SPSS Program (6th ed.). London: McGraw-Hill Education.

Sam, N., Gürsakal, S., ve Sam, R. (2010). Üniversite öğrencilerinin çevresel risk algısı ve çevresel tutumlarının belirlenmesi. Akademik Bakıs Dergisi, 20, 1-16.

Sönmez, E. ve Yerlikaya, Z. (2017). Ortaokul öğrencilerinin çevresel bilgi düzeyleri ve çevreye yönelik tutumları üzerine bir alan araştırmas1: Kastamonu ili örneği. Kastamonu Eğitim Dergisi, 25(3), 1239-1249.

Şimşekli, Y., (2004). Çevre Bilincinin Geliştirilmesine Yönelik Çevre Eğitimi Etkinliklerine İlköğretim Okullarının Duyarlılığı. Uludağ Üniversitesi Eğitim Fakültesi Dergisi, 17(1),83-92.

Tecer, S. (2007). Çevre için ĕgitim: Ballkesir ili ilköğretim öğrencilerinin çevresel tutum, bilgi, duyarlılık ve aktif katılım düzeylerinin belirlenmesi üzerine bir çalışma (Yayınlanmamış Yüksek Lisans Tezi). Zonguldak Karaelmas Üniversitesi Fen Bilimleri Enstitüsü, Zonguldak.

Teyfur, E. (2008). İlköğretim öğrencilerinin akademik başarılarının ve çevre kulübü çalışmalarının çevreye yönelik tutumlarına olan etkisi İzmir örneği. Ege Ĕ̆itim Dergisi, 9(1), 131-149.

Tuncer, G., Ertepinar, H., Tekkaya, C. ve Sungur, S. (2005). Environmental attitudes of young people in Turkey: effects of school type and gender. Environmental Education Research, 11(2), 215233.

Verdelone, T. H., Campbell, G., \& Alexandrino, C. R. (2019). Trabalhando educação ambiental com turmas do ensino fundamental I/Working environmental education with classes of elementary education I. Brazilian Journal of Development, 5(6), 4675-4687.

Wheaton, B., Muthen, B., Alwin, D., \& Summers, G. F. (1977), Assessing reliability and stability in panel models. Sociological Methodology, 8(1), 84-136

Yaşar, Z. (2013). İlköğretim II. Kademe öğrencilerinin çevreye yönelik bilgi, tutum ve davranışlarının fen başarıları açısından incelenmesi (Yayınlanmamış Yüksek Lisans Tezi). Gazi Üniversitesi Eğitim Bilimleri Enstitüsü, Ankara.

Yaşaroğlu, C. ve Akdağ, M. (2013). İlköğretim birinci kademe için çevreye yönelik tutum ölçeği: geçerlik ve güvenirlik çalışması. Adıyaman Üniversitesi Sosyal Bilimler Enstitüsü Dergisi, 6(13), 253-275.

Yilmaz, O., Boone, W.J. \& Anderson, H.O. (2004). Views of elementary and middle school Turkish students toward environmental issues. International Journal of Scienece Education, 26(12), $1527-1546$. 
Yolcu, O. (2014). Cumhuriyetten (1923) günümüze (2013) ilköğretim birinci kademe hayat bilgisi ve fen ve teknoloji öğretim programlarının "çevre eğitimi" açısından incelenmesi (Yayınlanmamış Yüksek Lisans Tezi). Adnan Menderes Üniversitesi Sosyal Bilimler Enstitüsü, Aydın. 


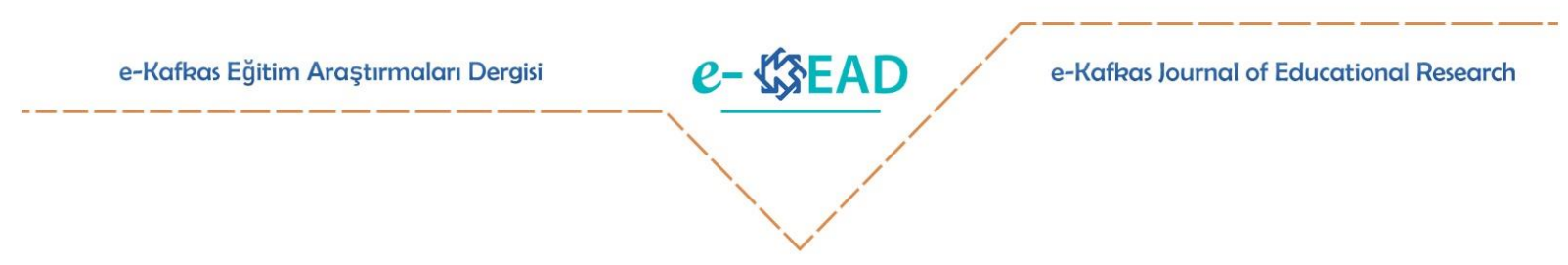

\section{Determining the Environmental Knowledge, Attitude, and Behavior of Fourth Grade Primary School Students}

\section{Beyza Selin UZUN}

\section{Burcu ŞENLER}

To cite this article: Uzun, B. S. ve Şenler, B. (2020). İlkokul dördüncü sınıf öğrencilerinin çevreye yönelik bilgi, davranış ve tutumlarının belirlenmesi. e- Kafkas Eğitim Araştırmaları Dergisi, 7, 413-429. doi:10.30900/kafkasegt.796058

\section{Research article}

Received: 17.09 .2020

Accepted:30.12.2020

\section{Introduction}

People should be educated and informed as necessary about the environment (Aydin and Çepni, 2012). In this context, environmental knowledge is one of the components of environmental education. Environmental knowledge, in general, helps individuals to understand environmental problems, to offer solutions to these problems, and to form ideas about the causes of these problems (Öztürk, 2013). Therefore, only having information about the environment seems to be a part of having environmental awareness. In addition, environmental education aims to have permanent and positive effects on individuals not only in the dimension of knowledge but also in the dimension of behavior by increasing individuals' awareness of the environment and nature (Şimşekli, 2004). By observing the positive behaviors of individuals towards their environment, it is possible to create an environmental consciousness in individuals and ultimately in the society. In this way, it can be mentioned that the human factor underlying environmental problems and the negative effects of this factor on our world can be minimized (Ceger \& Erten, 2018). The first step to be taken in the process of gaining positive behaviors towards the environment is to increase the positive attitudes towards the environment as a result of the planned and programmed environmental education that individuals will receive at an early age, as their knowledge level towards the environment increases (Gökçe, Kaya, Aktay, \& Özden, 2007; Yaşaroğlu \& Akdağ, 2013). Individuals who have sufficient knowledge about the environment will develop positive attitudes towards the environment and will acquire habits in this direction. As a result of the individuals who have environmental knowledge using this information and internalizing it in their daily lives, positive attitudes begin to develop in the context of the environment, and as a result of the development of positive attitudes, environmentally friendly and positive behaviors towards the environment are displayed (Karaismailoğlu, 2018; Öztürk, 2013).

In order to emphasize the importance of environmental education for children and to increase environmental awareness, this study was carried out considering as an integrative study that includes environmental knowledge, attitude and behavior will contribute to the literature and guide new studies. It is thought that the scale developed in the context of evaluating environmental awareness and environmentally friendly behaviors in primary education will contribute to the relevant literature on environmental education. In addition to these, characteristics such as knowledge, behavior and attitude towards the environment of primary school fourth grade students at the basic education level will be determined in line with the research, and in this context, it will be tried to contribute to the training of students as environmentally literate individuals. In this context, it was planned to develop a scale in order to see the knowledge, attitudes and behaviors of primary school fourth grade students towards the environment more clearly and to apply this scale to students by carrying out validity and reliability 
studies, and to conduct comprehensive research by interpreting the data obtained in this context. From this point of view, it is seen that students should only have the necessary environmental knowledge, positive attitudes towards the environment and environmentally friendly behaviors in order to raise environmentally literate individuals in line with the objectives of basic education. It can be said that this study is very important in terms of developing a measurement tool that can measure knowledge, attitudes and behaviors towards the environment at the primary education level.

In this study, it was aimed to determine the knowledge, behavior and attitudes of primary school fourth grade students towards the environment and to examine them according to some variables. Therefore, research questions are as follows:

- What is the level of knowledge, behavior and attitudes of primary school fourth grade students towards the environment?

- Do the knowledge, behavior and attitudes of primary school fourth grade students towards the environment differ according to their gender?

- Do the knowledge, behavior and attitudes of primary school fourth grade students towards the environment change according to the science course grade?

- Is there a relationship between the knowledge, behavior and attitudes of primary school fourth grade students towards the environment?

\section{Method}

This research was carried out by using survey design, one of the quantitative research methods. Survey design is used for studies aiming to collect data to determine certain characteristics of a group (Büyüköztürk et al., 2014). The study was carried out in three parts. In the first part of the study, Environmental Knowledge Scale, Environmental Behavior Scale and Environmental Attitude Scale were developed to measure students' knowledge, behavior and attitudes towards the environment. In the second part, a pilot study was conducted with 457 fourth grade volunteer students in a district in the Aegean Region. The validity and reliability analyses were utilized. Finally, the scales were applied to 292 fourth grade volunteers studying at primary schools in two districts in a province in the Southeastern Anatolia Region to answer the study's problems.

\section{Findings}

As a result of the analysis, it was found that the environmental knowledge, behavior and attitude scores did not differ according to gender but the scores of female students were found to be higher. In the examination made according to the science course grade, it was determined that the scores of knowledge and attitude scales differed significantly while the scores of behavior scale did not differ. A positive and significant relationship was determined among students' knowledge, behavior and attitudes towards the environment.

\section{Discussion, Conclusion and Recommendations}

In this study, knowledge, behavior and attitudes of primary school fourth grade students towards the environment were determined and analyzed according to some variables. First, the scales planned to be used in the study were developed. As a result of factor analysis and reliability calculations, the validity and reliability of the scales were provided. Then, sub-problems were investigated. It was determined that the environmental knowledge, behavior and attitude scores did not change depending on the gender variable. However, the environmental knowledge, behavior and attitude scores of the female students were higher than the male students. In this context, it can be said that female students are at a better level than boys in transforming their environmental knowledge into environmental behavior and attitude.

As a result of the research, the environmental knowledge scores of the students with very good grades were higher than the students with good grades. Unlikely, the environmental behavior scale scores of the students did not change regarding their grades. The environmental attitude scores of the students with very good science course grades are higher than the environmental attitude scores of the 
students with good grades. According to the findings of the research, it was observed that as the academic success of the students increased, their environmental knowledge and attitude levels increased.

It has been determined that there is a strong and positive relationship between primary school students' environmental knowledge and attitudes. This result indicates that as the students' level of knowledge about the environment increases, their attitudes towards the environment improve. Similarly, it can be said that as students' attitudes towards the environment increase, their level of knowledge about the environment also increases. There is a significant, if not very strong, relationship between students' environmental knowledge and behavior. There is a positive, high level and significant relationship between primary school students' environmental attitudes and behavior levels. It can be said that as students' attitudes towards the environment increase, their behavior towards the environment improves positively.

Considering the results obtained as a result of the research, activities and studies that will enable students to have positive attitudes and behaviors regarding the environment, not only to increase their knowledge, can be included in schools so that the environmental education to be given starting from basic education can be more effective. 
Ek 1. Ölçme Araçları

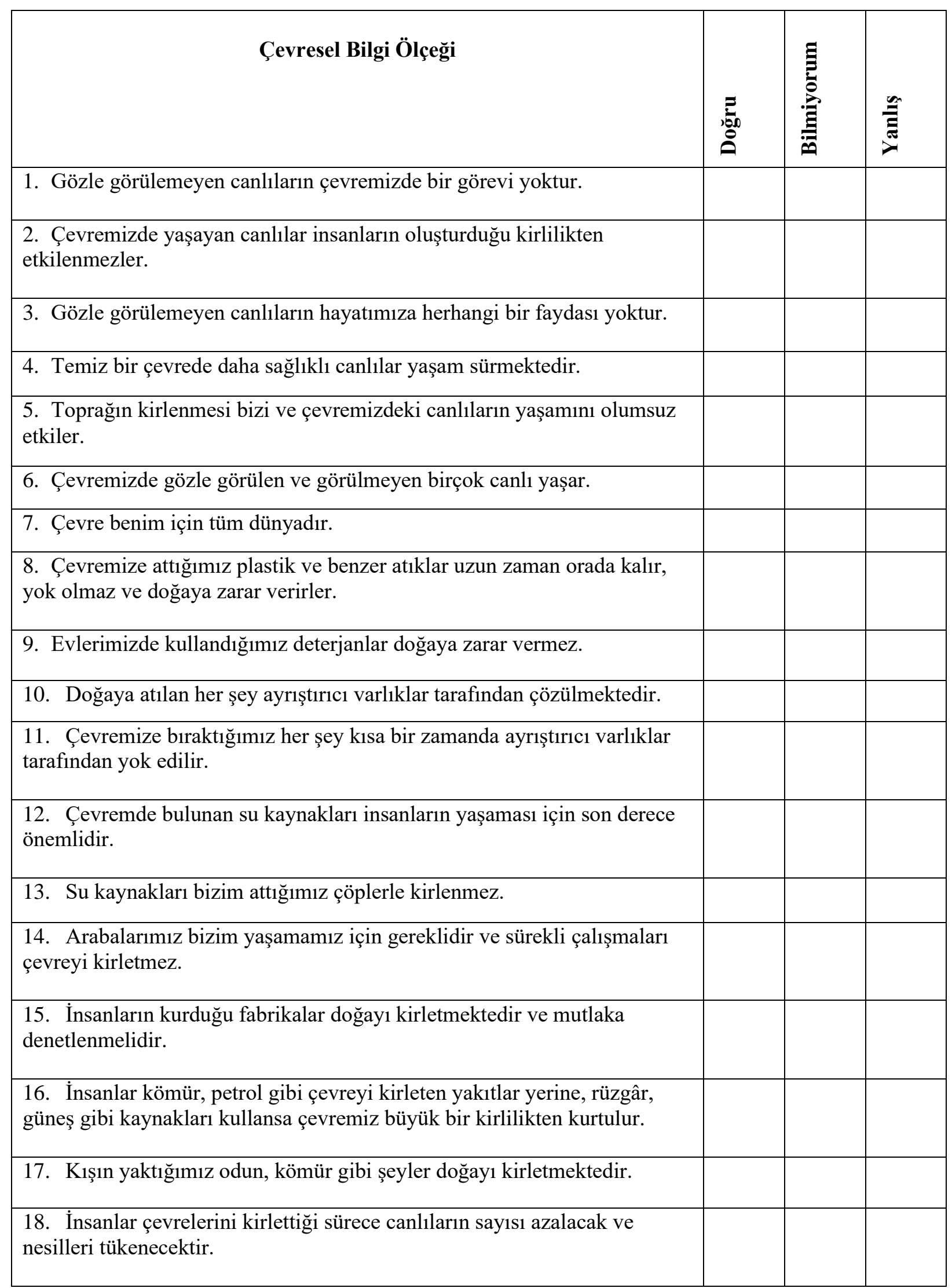




\begin{tabular}{|l|l|l|}
\hline \multicolumn{1}{|c|}{ Çevresel Davranış Ölçeği } & & \\
\hline & & \\
\hline 1.Doğayı kirleten birini gördüğümde onu uyarırım. & & \\
\hline 2.Çevremde zarar görmüş canlılar gördüğümde onlara yardım ederim. & & \\
\hline $\begin{array}{l}\text { 3.Su içtikten sonra hepsini bitiremezsem bardakta kalan suyu çöpe } \\
\text { dökmek yerine çevremdeki bitkilerin diplerine dökerim. }\end{array}$ & & \\
\hline 4.Çevremizde hayvanlara zarar veren birilerini görürsem uyarırım. & & \\
\hline $\begin{array}{l}\text { 5.Su kaynaklarını pisleten insanları gördüğümde onları mutlaka } \\
\text { uyarırım. }\end{array}$ & & \\
\hline 6.Evde gereksiz yere açık gördüğüm lambaları kapatırım. & & \\
\hline 7.Banyo yaparken gereksiz yere uzun süre suyu kullanmam. & & \\
\hline 8.Çöplerimi geri dönüşüm kutularına atarım. & & \\
\hline
\end{tabular}




\begin{tabular}{|c|c|c|c|}
\hline Çevresel Tutum Ölçeği & 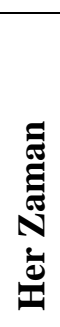 & 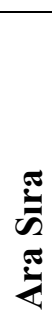 & 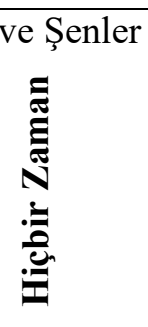 \\
\hline \multicolumn{4}{|l|}{ 1.Temiz bir çevrede yaşamak kadar güzel bir şey yoktur. } \\
\hline \multicolumn{4}{|l|}{ 2.Çevremizde bize zarar veren canlıların yok edilmesi beni üzmez. } \\
\hline \multicolumn{4}{|l|}{$\begin{array}{l}\text { 3.Bir yere gittiğimde oradaki çöpleri bir poşete toplamaktan } \\
\text { hoşlanırım. }\end{array}$} \\
\hline \multicolumn{4}{|l|}{$\begin{array}{l}\text { 4.Dünyanın herhangi bir yerinde çevre ile ilgili kötü bir haber } \\
\text { duymak beni üzer. }\end{array}$} \\
\hline \multicolumn{4}{|l|}{$\begin{array}{l}\text { 5.Ailemizde elektrik ve su kullanımı konusunda tasarruf yapmak } \\
\text { çevremize de çok büyük katkı sağlar. }\end{array}$} \\
\hline \multicolumn{4}{|l|}{$\begin{array}{l}\text { 6.Okulumuzda yapılan çevreyle ilgili etkinliklere katılmaktan } \\
\text { hoşlanırım. }\end{array}$} \\
\hline \multicolumn{4}{|l|}{ 7.Okulumuzda çevre koruma kolunda olmak beni mutlu eder. } \\
\hline \multicolumn{4}{|l|}{$\begin{array}{l}\text { 8.İnsanlar doğal yaşamın düzenini bozacak şekilde ev, ahır, garaj gibi } \\
\text { yapılar yapmamalıdır. }\end{array}$} \\
\hline \multicolumn{4}{|l|}{ 9.Çevremizdeki canlıların özgür bir şekilde yaşama hakkı vardır. } \\
\hline 10.Bitki ve hayvanlar kesinlikle yok edilmemelidir. & & & \\
\hline
\end{tabular}

